\title{
Approach to a patient with Excessive Daytime Sleepiness
}

\author{
Dang Nitika*, Tripathi Manjari** \\ ${ }^{*}$ PhD Student, Neurosciences Centre, All India Institute of Medical Sciences, New Delhi, ${ }^{* *}$ Additional Professor, \\ Department of Neurology, All India Institute of Medical Sciences, New Delhi
}

Indian J Sleep Med 2011; 6.4, 121-129

\section{Case vignette}

A 21 year old girl, college student, was referred to our Sleep Clinic for evaluation of her excessive drowsiness during the day hours.

Her symptoms started at the age of 17 years, when her family noticed that she seemed to need more sleep than her siblings and peers. This would often hinder her daytime functioning as she would be fatigued and "worn out" all the time and needed regular naps to refresh herself. When she avoided the naps, she would have an irresistible urge to sleep which she succumbed to and would doze off anywhere at any time. Recently, she had even burnt herself in one such "attack" where she had "dozed off" while cooking. At 19, she had her first spell of a sudden inability to move that was triggered by laughter. Her speech was slurred and her "knees became weak" for a few seconds, but she did not fall down. Events were unassociated with any alteration in consciousness, headaches, sensory disturbances, cardiopulmonary symptoms, visual disturbances or seizure activity. She also experienced a few incidents where she was unable to move her limbs, talk and "became stiff" for several minutes after waking up from sleep, which were suggestive of sleep paralysis. She attends college regularly but reports struggling academically though she had no history of any learning disorder.

Her sleeping habits indicated an altered sleep-wake pattern. She would usually stay awake until 2 or 3 am watching television or surfing the net and awakened

Address for correspondence

Dr Manjari Tripathi

Additional Professor, Department of Neurology, All India Institute of Medical Sciences, New Delhi. Email: manjari.tripathi1@gmail.com several times a night by terrifying dreams. On weekdays, she woke up at 8 am for college while on weekends, she preferred to sleep till $10 \mathrm{am}$. She took 2-3 half hour naps after college i.e between $2 \mathrm{pm}$ to $11 \mathrm{pm}$. These naps were refreshing for her and she remained active for 3-4 hours after each nap. She had 2-3 cups of coffee at college, which did help her to keep her awake and attentive.

She lives with her parents. She was socially not very active but spent time working out in the gymnasium. She drove a car for short distances on a daily basis and reported no motor vehicle accidents.

Her past medical history was unremarkable except for history of tonsillectomy at 14 years of age. Prior to the tonsillectomy, she regularly used anti-histaminics for rhinitis. Thereafter, she had not been on any drugs for any illness.

Her mother was diagnosed with narcolepsy without cataplexy at the age of 17 .

She had an overnight polysomnogram 2 years back, which her parents reported gave no explanation for her symptoms. The records of that previous sleep study were unavailable for review.

On examination, she appeared well, with a normal blood pressure. Oropharyngeal examination revealed a Mallampati Score of 1. Findings from her general medical examination, including her cardiopulmonary examination, were unremarkable, with normal heart sounds and no carotid bruits. Neurologic examination showed normal motor strength throughout, with normal reflexes.

A mental status examination showed her to be alert and able to make good eye contact. Her speech and language skills were normal, though she was slightly anxious. Her thought form was unremarkable and thought content lacked any delusional thinking or

Indian Journal of Sleep Medicine (IJSM), Vol. 6, No. 4, 2011 
hallucinations. A Mini Mental State Examination revealed no abnormality.

Her PSG findings revealed a reduced sleep latency, increase REM sleep, decreased REM sleep latency $(<20$ minutes), increased frequency of awakenenings in the form of microarousals and wake time after sleep onset (WASO). A Multiple sleep latency test (MSLT) was done the following morning, and revealed reduced REM sleep latency (3 sleep onset REM periods).

\section{Hypersomnia}

Hypersomnia is characterized by difficulty maintaining alertness during waking hours. The 2 nd edition of the International Classification of Sleep Disorders classifies hypersomnias. Narcolepsy due to medical conditions, menstruation-related hypersomnia, behaviorally induced insufficient sleep syndrome, hypersomnia due to medical condition, drug, or substance and secondary to another disorders ${ }^{1}$.

\section{Insufficient sleep:}

A night sleep of 7-8 hours is mandatory for optimal functioning. Insufficient sleep can be due to many reasons, some common ones being poor sleep hygiene, sleep deprivation, shift work, jet lag etc.

\section{Fragmented sleep:}

Sleep quality is equally important for a refreshing sleep. Disruption of sleep due to sleep maybe due to various reasons; common ones are discussed below:

\section{Sleep Disordered Breathing (SDB):}

This category is the most important cause of sleep fragmentation, though underplayed and less known in the general population due to lack of awareness.

Sleep disordered breathing may be from one end of the spectrum representing the mildest form i.e Upper airway resistance syndrome (UARS) to the other end of the spectrum representing severe obstructive sleep apnea.

SDB may be due to the abnormal anatomy, in the

Causes of excessive daytime sleepiness ${ }^{2}$

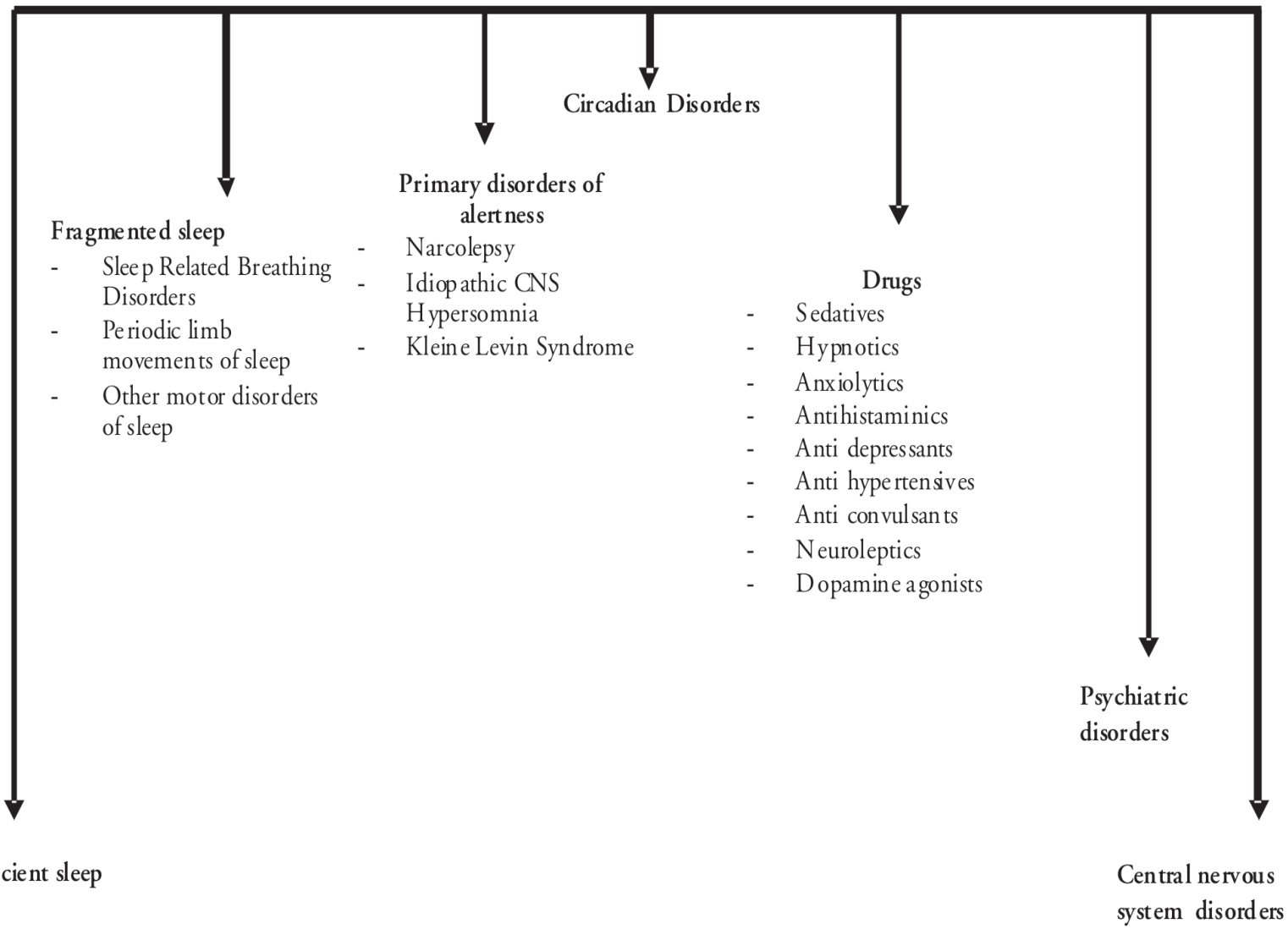


form of crowded oral cavity due to any reason- most common being obesity, crowding of upper airway, collapsibility of the upper airways worsened by the physiological changes during sleep (decreased muscle tone) etc ${ }^{1,3}$. Obstructive sleep apnea can be successfully managed by PAP therapy ${ }^{1}$.

\section{Periodic Limb Movements of Sleep}

Earlier known as nocturnal myoclonus, these repetitive movements in sleep are predominantly seen in the initial part NREM sleep ${ }^{3}$. PLMs are known to be associated with Restless leg syndrome, both are seen in conditions like deficiencies of iron and folate, renal disease, peripheral neuropathy, Parkinsonism and spinal disorders. Caffeine, anti depressants, neuroleptics etc. exacerbate these movements. Dopaminergic agonists are the drugs of choice in these patients. Benzodiazepines, opoids, anti-convulsants and beta blockers may also be used in these patients .

\section{Other medical conditions}

Medical conditions causing pain of any nature such as arthritis, fibromyalgia, spondylosis, cardiac conditions such as nocturnal angina, paroxsymal nocturnal dyspnea, respiratory conditions like COPD, restrictive pulmonary disease, asthma, GI disorders like gastroesophageal reflux disorder (GERD), irritable bowel syndrome (IBS), alcoholism, urinary dysfunction etc are also important causes of fragmentation of sleep. Appropriate management of the medical conditions is beneficial to manage these causes of EDS 4 .

\section{Primary disorders of alertness}

\section{Idiopathic Hypersomnia}

Patients with idiopathic hypersomnia have EDS regardless of the amount of sleep obtained. The nocturnal sleep is normal, and none of the associated features of narcolepsy are present. Naps are generally not refreshing. ICSD2 Criteria for hypersomnia with long sleep time include EDS almost daily for 3 months, prolonged nocturnal sleep time (more than 10 hours), waking up from nocturnal sleep or naps is difficult, and no other disorder better explains this ${ }^{1}$. The polysomnogram shows short sleep latency (time to sleep onset) and greater than 10 hours of sleep. The MSLT shows a mean sleep latency of less than 8 minutes, and less than 2 episodes of REM.

\section{Narcolepsy}

EDS is the first and most disabling symptom of
Narcolepsy, which is defined as a neurologic disorder characterized by excessive sleepiness in the form of sleep attacks with manifestations of rapid eye movement (REM) sleep physiology during wakefulness (eg: cataplexy, sleep paralysis and hypnagogic hallucinations). Automatic behavior, nocturnal sleep disturbance, visual changes (blurred vision, diplopia, ptosis), memory lapses, associated sleep disorders, obstructive sleep apnea, REM sleep behavior disorder, periodic limb movement disorder etc. may be associated with narcolepsy ${ }^{5,6}$.

Clinical subtypes of Narcolepsy ${ }^{\top}$ :

\begin{tabular}{|c|c|c|}
\hline SN & Subtype & Characteristics \\
\hline 1 & $\begin{array}{l}\text { Narcolepsy with } \\
\text { cataplexy with } \\
\text { normal hypocretin- } \\
1 \text { levels in the CSF. }\end{array}$ & $\begin{array}{l}\text { Normal hypocretin- } 1 \text { levels are seen in } \\
\text { upto } 10 \% \text { of patien ts }\end{array}$ \\
\hline 2 & $\begin{array}{l}\text { Narcolepsy without } \\
\text { cataplexy with low } \\
\text { hyp oc retin-1 le vels } \\
\text { in the CSF. }\end{array}$ & $\begin{array}{l}\text { Low CSF hypocretin- } 1 \text { levels }(<110 \\
\text { pg/mL) are present in up to } 10 \% \text { to } \\
20 \% \text { of cases of HLA DQB } 1{ }^{*} 0602- \\
\text { positive } \\
\text { narcolepsy without cataplexy } \\
\text { HLA DQB } 1^{*} 0602-n e g a t i v e ~ n a r c o l e p s y \\
\text { without cataplexy } \\
\text { patients generally have normal CSF } \\
\text { hypocretin-1 levels }\end{array}$ \\
\hline 3 & $\begin{array}{l}\text { Narcolepsy with } \\
\text { cataplexy-like or } \\
\text { atypical } \\
\text { epis odes }\end{array}$ & $\begin{array}{l}\text { Low CSF hypocretin- } 1 \text { levels }(<110 \\
\mathrm{pg} / \mathrm{ml}) \text { are present in up to } \\
20 \% \text { of cases }\end{array}$ \\
\hline 4 & Isolated cataplexy & Rare familial cases with early onset \\
\hline 5 & $\begin{array}{l}\text { Hypocretin gene } \\
\text { mutations }\end{array}$ & $\begin{array}{l}\text { Early-onset ( } 6 \text { month of age) } \\
\text { narcolepsy with cataplexy due to } \\
\text { prep rohypocretin mutation has been } \\
\text { described }\end{array}$ \\
\hline
\end{tabular}

Narcolepsy can be secondary to several causes

1. Narcolepsy with cataplexy

- Brainstem lesions

- Immune

- Degenerative

- Infectious

- Inflammatory

- Neoplastic (craniopharyngioma, gliomas, pituitary, and hypothalamic tumors)

- Vascular (stroke or arteriovenous malformations)

- Cerebellar ataxia

- Coffin-Lowry syndrome (possible)

- Hydrocephalus secondary to space-occupying lesions

- Multiple sclerosis (hypothalamic)

- Neiman-Pick type C disease

- Norrie's disease

- Paraneoplastic syndrome (associated with anti-Ma2 
antibodies)

- Sarcoidosis (hypothalamic)

- Tumors (hypothalamic)

- Viral illness (unspecified)

2. Narcolepsy without cataplexy

- Head trauma

- Multiple sclerosis

- Multiple system atrophy

- Myotonic dystrophy

- Parkinson disease

- Prader-Willi syndrome

3. Narcolepsy and sleep apnea (Sleep onset REM periods and excessive sleepiness persist after adequate therapy of sleep apnea)

- Myotonic dystrophy

- Prader-Willi syndrome

Several medicines and substances used in day to day clinical practice may cause drowsiness and are listed in the table below.

Medications and substances commonly associated with sleepiness

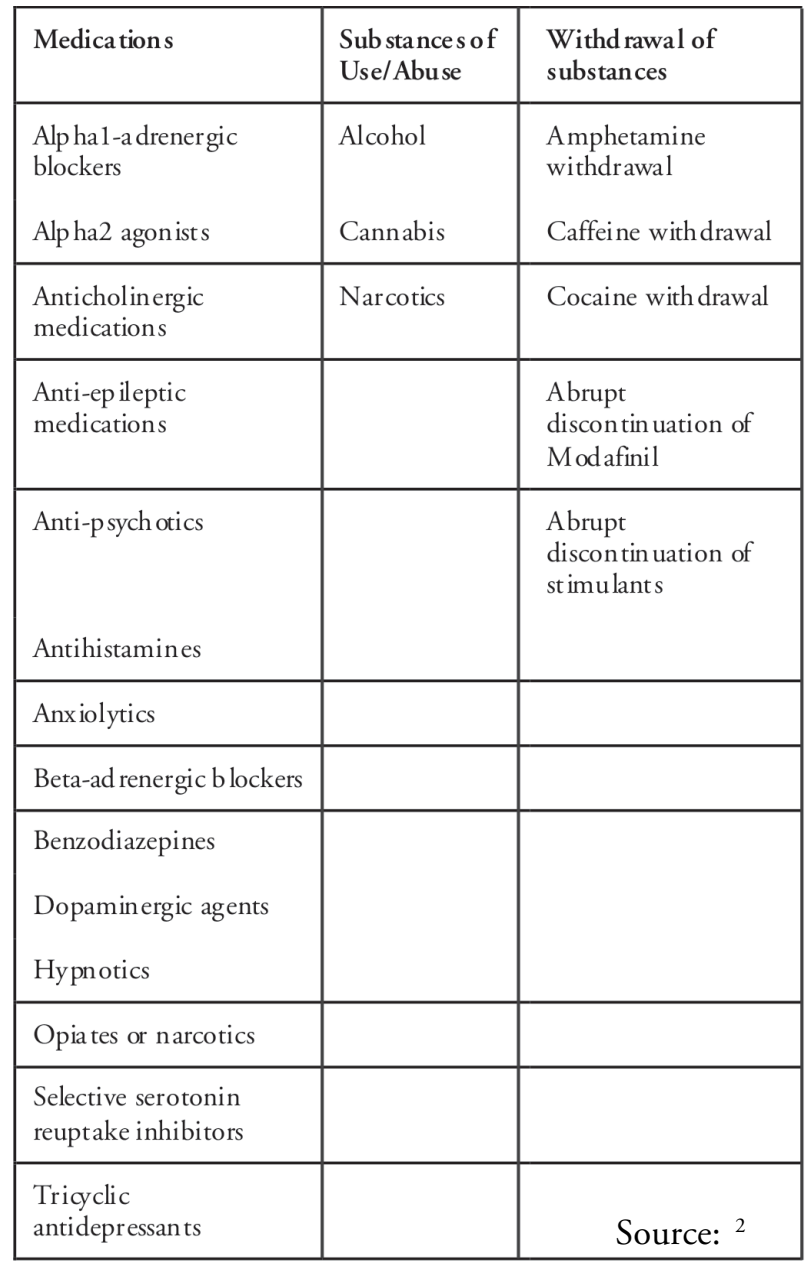

Indian Journal of Sleep Medicine (IJSM), Vol. 6, No. 4, 2011

\section{Evaluation of a patient with EDS:}

A thorough clinical history differentiating tiredness and fatigue from sleepiness, followed by a detailed examination is the first step in the evaluation.

\section{Tools for measuring EDS}

1. The Stanford Sleepiness Scale (Glenville M; 1978): This Likert scale measures sleepiness over time. It is particularly useful to study sleep deprivation, sleep fragmentation and circadian rhythms. Scores on SSS requires standardization to remove the discrepancy among subject ratings ${ }^{9}$.

2. The Karolinska Sleepiness Scale (Kaida K, 2006): This is a 9 point is also a Likert Scale $(1=$ very alert to $9=$ very sleepy) which measures the level of drowsiness subjectively in a patient complaining of EDS ${ }^{10}$.

3. The Epworth Sleepines Scale (Johns, 1991): This eight item questionnaire measuring subjective sleepiness has scores from 0 (not sleepy) to 24 (excessive sleepiness). A score of $>10$ is suggestive of sleepiness and $>15$ suggests excessive daytime sleepiness. ESS has a high sensitivity (93.5\% - 97\%) and specificity $(100 \%)^{11}$.

4. Visual Analogue Scale (VAS): is a horizontal line $100 \mathrm{~mm}$ long that represents the two extremes from "very alert" to "very sleepy" .The VAS is the distance between the patients mark on the line and the extreme end. The VAS requires standardization of scores ${ }^{13,14}$.

5. Sleep -Wake Activity Inventory: is a 35 item scale that has subscales enquiring about sleep habits and disorders. It can assess several aspects of the sleep. The patient is tested at random intervals of a few seconds. A "lapse" in the performance is said to occur when the reaction time is greater than 500 msces.Currently, there are no studies to prove a standardized measure of sleepiness based on the reaction time.

6. Infrared Reflectance Oculography during a Vigilance test- This test based on infrared oculography, is a relatively newer computer based test that takes 10 15 minutes to administer. A frame with the prescription glasses also includes tiny infrared transducers with a microprocessor. Though it has not been widely used, studies suggest it to be a promising test ${ }^{12,15}$.

7. Video Camera Methods for detecting Eyelid ClosurePERCLOS: This technique measures eyelid closures, 
which are stronger and longer than average blinks and more prolonged eyelid closures. Position of the eyelids and pupil size can also be measured by this technique. This was mainly developed to detect sleepiness or drowsiness in drivers ${ }^{12}$.

\section{Other Oculometric Tests ${ }^{12}$}

- Pupillary Unrest Index: Is a sensitive test as it varies with the time of the day and increases with sleep deprivation.

- Saccadic Eye Movments: The velocity of the saccades reduces with sleep deprivation.

- Pupillary reflex : Increased latency of the light reflex and the consensual light reflex is seen in sleep deprived patients.

9. Actigraphy: An actigraph is an ambulatory activity monitoring device that is placed on the wrist of the patient, like a watch. It is used for sleep assessment in clinical sleep research, and as a diagnostic tool in sleep medicine, especially in patients with insomnia and hypersomnia ${ }^{14,15,16}$.

10. Sleep Diary/ Log: During clinical evaluation, a sleep log enables the physician to see the sleeping patterns and sleep habits of the patients ${ }^{17}$.

11. Screening Blood Tests: Screening for anemia, drug intoxication and other medical causes of EDS can be ruled out.

12. Psychiatric Evaluation and Psychological Testing: In patients where mood disorders, psychosis, conversion disorders or malingering is suspected ancillary evaluation is required.

\section{Polysomnographic Evaluation:}

13. Overnight Polysomnogram: An overnight polysomnogram is indicated in patients with excessive daytime sleepiness to rule out conditions like sleep disordered breathing, periodic limb movements of sleep etc. which may be causing the daytime somnolence.

14. Multiple Sleep Latency Test (MSLT): is a test designed to check on a patients propensity to fall asleep at regular intervals. This test is diagnostic of narcolepsy, which is a major cause of EDS, where a mean sleep latency of 8 minutes or less is observed with 2 or more sleep onset REM periods (SOREMP's) $^{18,19}$.

15. Maintainence of Wakefulness Test (MWT): This test measures the propensity of a person to stay awake. The 40 minute protocol comprising of 4 trials separated by 2 hours. The latency of sleep onset is recorded during this test. Healthy or alert individuals will not fall asleep during this test ${ }^{12,18,19}$.

16. Oslers Test: This alternative to the MWT was proposed in 1997 as a simpler and cheaper modification. The patient sits semi reclined in a chair and is supposed to push a button following a flash of light that appears at a regular interval of 3 seconds. Failure to push the button for 7 consecutive stimuli is said to be diagnostic for the patient being alseep ${ }^{12,18}$.

\section{Differential Diagnosis}

Common and important causes of excessive daytime sleepiness (EDS) 5,8,12 $^{5}$

\begin{tabular}{|c|c|c|}
\hline $\begin{array}{l}\text { Case of EDS } \\
\text { Insufficient sleep time }\end{array}$ & $\begin{array}{l}\text { Clinical history } \\
\text { - Inadequate amount of sleep } \\
\text { - Poor sleep "hygiene", such as irregular } \\
\text { sleep and wake times } \\
\text { - Many forms of insomnia can impair } \\
\text { night sleep and have daytime consequences }\end{array}$ & $\begin{array}{l}\text { Treatment } \\
\text { - Increase sleep time } \\
\text { - Improve sleep hygience / educations about } \\
\text { appropriate sleep behaviors } \\
\text { - Specific therapies bases on the type of insomnia may } \\
\text { be used e.g. relaxation techniques etc. }\end{array}$ \\
\hline Sleep apnea & $\begin{array}{l}\text { - Loud snoring, gasping or cessations of } \\
\text { breathing (apnea) during sleep } \\
\text { - Upper airway abnormalities } \\
\text { - Use of sedatives / alcohol }\end{array}$ & $\begin{array}{l}\text { - Weight loss, avoiding sedatives } \\
\text { - Positional therapy (i.e. avoid sleeping supine) } \\
\text { - Continuous positive airway pressure (CPAP), or } \\
\text { bilevel positive airway pressure (BIPAP) } \\
\text { - Dental appliance } \\
\text { - Surgery (less commonly) } \\
\text { - After these treatments are implemented, modafinil } \\
\text { may be useful adjunct }\end{array}$ \\
\hline Narcolepsy & - Must have daytime sleepiness & - Scheduled naps \\
\hline
\end{tabular}




\begin{tabular}{|c|c|c|}
\hline & $\begin{array}{l}\text { - Cataplexy (loss of muscle tone with } \\
\text { emotional stimuli) is pathognomonic } \\
\text { - Sleep paralysis } \\
\text { - Hypnagogic hallucinations } \\
\text { - Fragmented noctumal sleep }\end{array}$ & $\begin{array}{l}\text { - For excessive daytime sleepiness (EDS) : modafinil, } \\
\text { stimulants } \\
\text { - For cataplexy : sodium oxybate, tricyclic } \\
\text { antidpressants, selective serotonin reuptake inhibitors } \\
\text { (SSRLs) and venlafaxine }\end{array}$ \\
\hline Idiopathic hypersomina $(\mathrm{IH})$ & $\begin{array}{l}\text { - Despite adequate sleep time, prominent } \\
\text { sleepiness without other rapid eye } \\
\text { movement (REM) sleep related features } \\
\text { of narcolepsy } \\
\text { - Occasionally associated with Raynaud's } \\
\text { phenomenon } \\
\text { - Sleep "drunkenness" is a common feature }\end{array}$ & - Stimulants and modafinil may be helpful \\
\hline $\begin{array}{l}\text { Recurrent hypersomnia } \\
\text { (Kleine-Levin Syndrome) }\end{array}$ & $\begin{array}{l}\text { - More commonly seen in young males } \\
\text { - Episodes of severe somnolence that lasts } \\
\text { day to weeks, and recurs weeks or } \\
\text { months apart } \\
\text { - Congnitive and behavioural disrubances, } \\
\text { including confusion, binge eating, } \\
\text { hypersexuality }\end{array}$ & $\begin{array}{l}\text { - Lithium may be helpful in reducing attacks } \\
\text { - Stimulants and modafinil may be useful in } \\
\text { symptomatic management }\end{array}$ \\
\hline Circadian Rhythm Disorders & - Shift work & $\begin{array}{l}\text { - Sensible scheduling practices } \\
\text { - Light therapy } \\
\text { - Modafinil } \\
\text { - Melatonin may be useful in the blind }\end{array}$ \\
\hline $\begin{array}{l}\text { Restless legs Syndrome (RLS) } \\
\text { \& Periodic Limb Movement } \\
\text { Disorders (PLMD) }\end{array}$ & $\begin{array}{l}\text { - Restless feeling in legs that occurs at } \\
\text { rest at right and resolves with movement } \\
\text { - Leg jerks or kicking during sleep associated } \\
\text { with fragmented sleep } \\
\text { - RLS is often associated with increases } \\
\text { arousal but higher doses of dopaminergic } \\
\text { agonists have been associated with } \\
\text { sleepiness particularly in Parkinson disease }\end{array}$ & $\begin{array}{l}\text { - Address reversible causes e.g. iron deficiency } \\
\text { - Minimize high dose dopaminergic agonists } \\
\text { - Ensure upper airway resistance is not contributing } \\
\text { to arousals }\end{array}$ \\
\hline Neurological conditions & $\begin{array}{l}\text { Commonly associated with sleepiness: } \\
\text { - Parkinsons disease } \\
\text { - Other neurodegenerative disorders } \\
\text { - Multiple sclerosis } \\
\text { - Stroke } \\
\text { - Epilepsy } \\
\text { - Neuromuscular disorders } \\
\text { - Structural brain disorders e.g affecting } \\
\text { midline projecting systems, bithalamic, } \\
\text { or bi cortical }\end{array}$ & $\begin{array}{l}\text { - Management of underlying neurological condition } \\
\text { - Stimulants and modafinil may be helpful } \\
\text { - Treatment of apnea may be particularly important as } \\
\text { there is an increases incidence in many of these } \\
\text { conditions }\end{array}$ \\
\hline Medical conditions & $\begin{array}{l}\text { Commonly associated with sleepiness : } \\
\text { - Respiratory disorders e.g chronic } \\
\text { obstructive pulmonary disease (COPD), } \\
\text { asthma } \\
\text { - cardiac: congestive heart failure } \\
\text { - renal : chronic renal failure } \\
\text { - rheumatologic : arthritis, inflammatory } \\
\text { disorders e.g. lupus } \\
\text { - malignancy hepatic : liver failure }\end{array}$ & $\begin{array}{l}\text { - Management of underlying medical condition } \\
\text { - Avoid use of sedating therapies where possible }\end{array}$ \\
\hline
\end{tabular}

Indian Journal of Sleep Medicine (IJSM), Vol. 6, No. 4, 2011 


\begin{tabular}{|c|c|c|}
\hline Psychiatric Disorders & $\begin{array}{l}\text { - Mood disorders } \\
\text { - Anxiety disorders } \\
\text { - Schizophrenia and other psychotic } \\
\text { disorders }\end{array}$ & $\begin{array}{l}\text { - Management of underlying psychiatric condition } \\
\text { - Choice of psychoactive medications that minimize } \\
\text { sedation or preferentially enhances alertness where } \\
\text { possible }\end{array}$ \\
\hline $\begin{array}{l}\text { Medication-induced } \\
\text { somnolence }\end{array}$ & $\begin{array}{l}\text { - Benzodiazepines } \\
\text { - Barbiturates } \\
\text { - Other "sleeping pills" } \\
\text { - Antidepressants } \\
\text { - Antipsychotics } \\
\text { - Over the counter agents such as } \\
\text { antihistamines }\end{array}$ & $\begin{array}{l}\text { - Minimize or stop the offending medication where } \\
\text { possible } \\
\text { - Appropriately time medications } \\
\text { - Institute specific therapies for underlying sleep } \\
\text { disorders }\end{array}$ \\
\hline
\end{tabular}

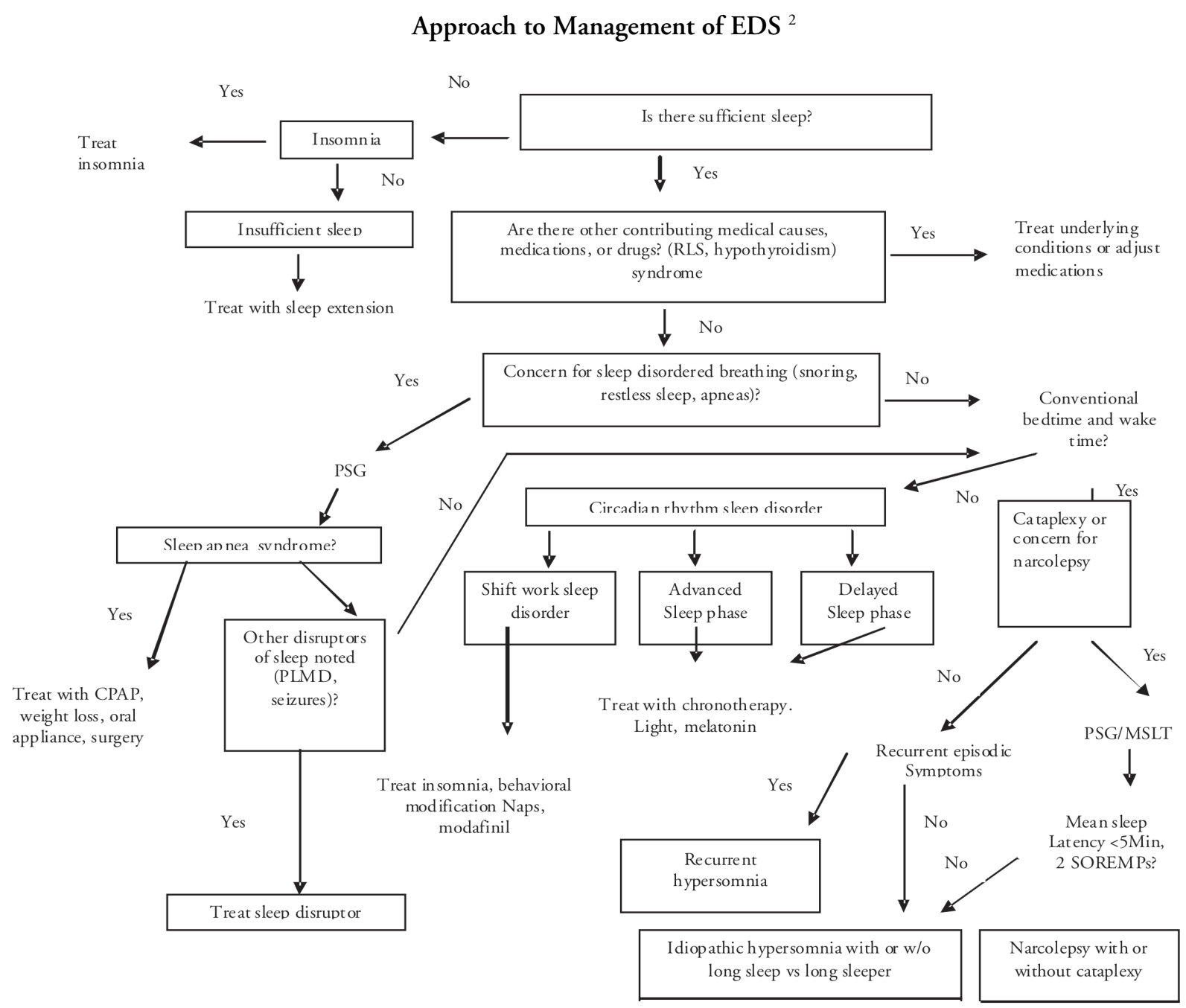

\section{Consequences of excessive sleepiness}

Consequences of excessive sleepiness include a greater risk of accidents, both due to the disorder itself and the drug effects (vehicular, industrial, or household), increased absenteeism, reduced work productivity, poor academic performance, mood disorder (depression or

irritability), and impaired interpersonal relationships. All these ultimately lead to a poor quality of life ${ }^{3}$.

\section{Treatment modalities}

\section{Behavioural therapy}

Patient, caregiver and family counseling is a must on the Indian Journal of Sleep Medicine (IJSM), Vol. 6, No. 4, 2011 
importance of sleep, sleep hygiene practices, behaviors affecting sleep and risks associated with the daytime somnolence. Patient should be introduced to relaxation techniques for sleep induction. The importance of pharmacotherapy should be emphasized and treatment seeking behavior should be promoted. For underlying psychiatric conditions, psychotherapy and counseling sessions should be promoted as an adjuvant to the pharmacotherapy. Dietary habits and physical exercise should also be discussed.

\section{Scheduled naps}

Though sleeping during the day is not promoted. However, if the patient cannot resist sleeping, he/she may take1-2 scheduled naps a day, each not exceeding 15-20 minutes. This is not the primary line of treatment but may be an adjuvant to pharmacotherapy in patients of narcolepsy.

\section{Role of surgery in OSA}

Various surgical procedures have been used to treat OSA. None other than tracheotomy have been shown to be consistently effective. The most common surgery for OSA is uvulopalatopharyngoplasty (UPPP); other surgical modalities are : Laser-assisted uvulopalatoplasty, Palatal implants, Radiofrequency tissue ablation, Nasal surgery and Trans-nasal insufflation. These surgeries have little role in the treatment of OSA.

\section{Pharmacotherapy:}

1. OSA: No drug has shown efficacy better than nasal PAP therapy. Mirtazapine and Donepezil have been tried in OSA though with little success.

\section{Narcolepsy:}

Caffeine: in the form of sodas and coffee may provide temporary relief in sleepiness.

CNS stimulants: are the mainstay of treatment. These increase wakefulness, vigilance and performance.

The table below lists these medications with there side effects. ${ }^{6,2}$

\section{Nasal PAP therapy for OSA}

Although there is clearly a significant impact of CPAP on excessive daytime sleepiness (EDS), it may still persist in a significant proportion of patients Other treatment modalities which contribute are: weight loss, positional therapy, oral appliances (mandibular advancement) and upper airway surgery(UPPP), treatment of ENT conditions like congestion, sinusitis etc. $^{22}$

Indian Journal of Sleep Medicine (IJSM), Vol. 6, No. 4, 2011
Table showing medication used in narcolepsy

\begin{tabular}{|c|c|c|c|c|}
\hline Medication & $\begin{array}{l}\text { Dose } \\
(\mathrm{mg})\end{array}$ & $\begin{array}{c}\text { Maintenance } \\
\text { Dose } \\
\text { (mg/day) }\end{array}$ & Regimen & Side effects \\
\hline Modafinil & $100-200$ & $100-400$ & QID, BD & $\begin{array}{c}\text { Headache, GI } \\
\text { irritab ility, Nause a }\end{array}$ \\
\hline $\begin{array}{l}\text { Methypheni } \\
\text { date }\end{array}$ & $5,10,20$ & $20-60$ & QID, BD & $\begin{array}{l}\text { Head ache, } \\
\text { tachycardia, } \\
\text { arrhythmia, } \\
\text { anorexia, we ight } \\
\text { loss, dependence } \\
\text { and abuse }\end{array}$ \\
\hline $\begin{array}{l}\text { Methypheni } \\
\text { date } \\
\text { extended } \\
\text { release }\end{array}$ & $\begin{array}{c}10,20 \\
30 \mathrm{SR} \\
10\end{array}$ & $20-60$ & QID, BD & $\begin{array}{l}\text { Head ache, } \\
\text { tachycardia, } \\
\text { arrhythmia, } \\
\text { anorexia, we ight } \\
\text { loss, dependence } \\
\text { and abuse }\end{array}$ \\
\hline $\begin{array}{l}\text { Amphetami } \\
\text { ne }\end{array}$ & $\begin{array}{c}5,7.5 \\
10,12.5 \\
15,20 \\
30\end{array}$ & $10-60$ & QID, BD & $\begin{array}{c}\text { Headache } \\
\text { tachycardia, } \\
\text { arrhythmia, } \\
\text { anorexia, we ight } \\
\text { loss, hypertension, } \\
\text { dependence and } \\
\text { abuse }\end{array}$ \\
\hline $\begin{array}{l}\text { Dextroamp } \\
\text { hetamine }\end{array}$ & $\begin{array}{c}5,10,15 \\
\text { SR }\end{array}$ & $10-60$ & QID, BD & $\begin{array}{l}\text { Anorexia, Weight } \\
\text { loss, headache, } \\
\text { tachycardia, } \\
\text { behaviou ral } \\
\text { chan ge, seizures }\end{array}$ \\
\hline $\begin{array}{l}\text { Sodium } \\
\text { Oxybate }\end{array}$ & $\begin{array}{l}2.25-4.5 \\
\text { in } 4.5-9 \\
\text { ml fluid }\end{array}$ & $2.25-4.5$ & HS & $\begin{array}{c}\text { Confusion, } \\
\text { impaired walking, } \\
\text { exacerbation of } \\
\text { sleep walking, } \\
\text { hallucination, } \\
\text { psych osis, } \\
\text { respiratory } \\
\text { depression, abuse. }\end{array}$ \\
\hline
\end{tabular}

\section{Conclusion}

EDS impacts significantly all spheres of functioning it can result in jeopardizing employment, lifestyle, safety and relationships. It is necessary that a meticulous history and management of these be done to improve the individuals functioning. At all stages basic measures of sleep hygiene and sleep practice must be advised. Realistic part by part goal setting and improvement are required.

\section{References}

1. American Academy of Sleep Medicine :The International Classification of Sleep Disorders: diagnostic and coding manual, 2nd ed. , Westchester: AASM; 2005

2. Tsai S.C; Excessive Sleepiness; Clin Chest Med 31 (2010) 341-35.

3. Chervin RD. Periodic leg movements and sleepiness in 
patients evaluated for sleep-disordered breathing. Am J Respir Crit Care Med. 2001 Oct 15;164(8 Pt1):1454-8. PubMed PMID: 11704595.

4. Stroe Alice F.; Roth Thomas; Jefferson Catherine; et al.; Comparative levels of excessive daytime sleepiness in common medical disorders; Sleep 2010: 11 (9): 890-896.

5. Johns $\mathbf{M W}$; What is excessive daytime sleepiness? Sleep diagnostics and treatment (2009) chapter 2: 1-36.

6. Avidan A.Y, Narcolepsy and Idiopathic Hypersomnia; ACCP Sleep Medicine Board Review Course 2008;35-50

7. Lee-Chiong T.,Excessive sleepiness; Sleep Medicine: Essentials and Reviews. Chapter 4; 133-170

8. Pagel J.F; Excessive Daytime Sleepiness; American Family Physician(2009); 79(5): 391-396

9. Glenville M, Broughton R. Reliability of the Stanford Sleepiness Scale compared to short duration performance tests and the Wilkinson Auditory Vigilance Task. Adv Biosci. 1978 Jul 24-25; 21:235-44. PubMed PMID: 755721.

10. Kaida K, Takahashi M, Akerstedt T, Nakata A, Otsuka Y, Haratani T, Fukasawa K.Validation of the Karolinska sleepiness scale against performance and EEG variables. Clin Neurophysiol. 2006 Jul; 117 (7): 1574-81. Epub 2006 May PubMed PMID: 16679057.

11. Johns $\mathbf{M W}$; A new method for measuring daytime sleepiness: The Epworth Sleepiness Scale; Sleep (1991); 14(6):540-5

12. Moldofsky H. Evaluation of daytime sleepiness. Clin Chest Med. 1992 Sep;13(3):417-25. Review. PubMed PMID: 1521410 .

13. Wilhem B., Giedke H., Ludtke H., Bittner E., Hoffmann A., Wilhelm $\mathrm{H}$., Daytime variations in the central nervous system activation measured by a pupillographic sleepiness test. J.Sleep Res, (2001) 10(1):1-7
14. Pilcher JJ, Pury CL, Muth ER. Assessing subjective daytime sleepiness: an internal state versus behavior approach. Behav Med. 2003 Summer;29(2):60-7.PubMed PMID: 15147104.

15. Dinges DF, Mallis MM, Maslin G., Powell JW.; Evaluation of techniques for ocular measurement oas an index of fatigue and the basis for alertness management, in DOT HS 808762 (1998).

16. Sadeh A. The role and validity of actigraphy in sleep medicine: an update. Sleep Med Rev. 2011 Aug;15(4):25967. Epub 2011 Jan 14. Review. PubMed PMID:21237680

17. Usui A, Ishizuka Y, Obinata I, Okado T, Fukuzawa H, Kanba S. Validity of sleep log compared with actigraphic sleepwake state. Psychiatry Clin Neurosci. 1998 Apr;52(2):1613. PubMed PMID: 9628127.

18. Reynolds CF 3rd, Coble PA, Kupfer DJ, Holzer BC. Application of the multiple sleep latency test in disorders of excessive sleepiness. Electroencephalogr Clin Neurophysiol. 1982 Apr;53(4):443-52. PubMed PMID: 6175506

19. Nakamura H, Takara C, Yamashiro K, Nakamura C, Okada T, Tohyama K. [Multiple sleep latency test (MSLT) and maintenance of wakefulness test (MWT)]. Nihon Rinsho. 2009 Aug;67(8):1569-75. Japanese. PubMed PMID: 19768942.

20. Kryger MH, Roth T, Dement WC, ed. Principles and Practice of Sleep Medicine, 4th ed. Philadelphia: Elsevier Saunders; 2005.

21. Morgenthaler T.I et al; Practice Parameters for the Treatment of Narcolepsy and other Hypersomnias of Central Origin (2007); An American Academy of Sleep Medicine Report SLEEP:30(12)

22. McNicholas, WT; Bonsignore, MR; Outcomes of OSA and indications for different therapies; J Clin. Sleep Med. (2009): 11 (2)

23. Mahmood $\mathbf{M}$, Kushida CA. Excessive daytime sleepiness. Handb Clin Neurol. 2011;99:825-31. PubMed PMID: 21056230 